ISSN: 0377-6395
e-ISSN: 2651-4214

\title{
Alternatif ve kafes yetiştirme sistemleri ile üretilen perakende yumurtaların kalite özellikleri
}

\author{
Eda ILHAN TEKIN ${ }^{1, a}$, Ece ÇETIN ${ }^{2, b}$, Seran TEMELLi ${ }^{3, c}$, Ayşegül EYIG ÖR ${ }^{3, d^{*}}$ \\ ${ }^{1}$ Yüksek Lisans Öğrencisi, Gölcük İlçe Sağllk Müdürlüğ̈̈ Obezite Birimi, 41650, Kocaeli; Bursa Uludă̆ Üniversitesi Sağllk Bilimleri Enstitüsü, \\ Besin Hijyeni ve Teknolojisi Anabilim Dal, Görükle Kampusu, 16059, Bursa, Türkiye \\ ${ }^{2}$ Tekirdağ Namık Kemal Üniversitesi, Besin Hijyeni ve Teknolojisi Anabilim Dall, 59030, Tekirdăg, Türkiye \\ ${ }^{3}$ Bursa Uludağ Üniversitesi Veteriner Fakültesi, Besin Hijyeni ve Teknolojisi Anabilim Dall, Görükle Kampusu, 16059, Bursa, Türkiye \\ ORCID: $0000-0001-7369-2130^{a}$; 0000-0002-8783-5507 ${ }^{b}$;0000-0002-8869-4929 ${ }^{c}$;0000-0002-2707-3117 ${ }^{d}$
}

MAKALE BILGISI /
ARTICLE
INFORMATION:
Geliş / Received:
15 Mart 19
15 March 19
Kabul/Accepted:
11 Mayıs 19
11 May 19
Anahtar Sözcükler:
Yetiştirme sistemleri,
yumurtaci tavuk,
yumurta kalite
özellikleri

Keywords:

Rearing systems, layer hen, egg quality traits
ÖZET:

\begin{abstract}
Alternatif (organik, serbest dolaşımlı ve kümes) ve kafes yetiştirme sistemleri ile üretilmiş A sınıfı kahverengi ve beyaz perakende yumurtaların dış ve iç kalite özelliklerinin belirlenmesi ve Yumurta Tebliği ile Yumurta Standardı'na uyumluluğunun değerlendirilmesi amacı ile yapılan bu çalışmada her bir yetiştirme sistemine ait 50'şer adet olmak üzere 200 kahverengi, 150 (serbest dolaşımlı hariç 3 sistemden) beyaz, toplam 350 adet yumurta incelendi. Yetiștirme sisteminin, kahverengi yumurtalarda, şekil indeksi, kabuk ağırlığı, kabuk kırılma direnci ve Haugh Birimi (HB), beyaz yumurtalarda ise şekil indeksi, kabuk kalınlığı ve hava boşluğu yüksekliği dışında incelenen tüm özellikler üzerine etkisinin istatistiksel olarak önemli $(\mathrm{p}<0.05)$ olduğu belirlendi. Tüm örneklerin yumurta ağırlığı, Türk Gıda Kodeksi Yumurta Tebliği 2014/55'ne uygun bulunurken, serbest dolaşıma ait kahverengi yumurtalarda hava boşluğu yüksekliğinin sınır değerin üzerinde $(6.75 \mathrm{~mm})$ olup uygun olmadığı saptandı. Kafes sistemindeki beyaz yumurtaların HB değerleri, Türk Standardı Tavuk Yumurtası - Kabuklu (TS1068) ile uyumlu iken bu değerin serbest dolaşım ve kafes sistemlerine ait kahverengi yumurtalarda gerekliliklerin altında olduğu saptandı. Kafes sistemindeki kahverengi yumurtaların diğerlerine göre daha yüksek șekil indeksi değerine (\% 79-küresel), beyazların daha düşük kabuk ağılığına (7.26 g) sahip olduğu; serbest dolaşım ve kafes sistemlerindeki kahverengi yumurtaların kabuklarının daha kalın $(0.32 \mathrm{~mm})$, organik sistemdeki beyaz ile kafes sistemindeki kahverengi yumurtaların kabuk kırılma direnci yönünden en dayanıklı olduğu; en koyu sarı rengin kafes sisteminde üretilen beyaz yumurtalarda, en açık sarı rengin ise organik yumurtalarda bulunduğu belirlendi. Sonuçta, tüm kalite kriterlerine uygun yumurta üretebilecek 'tek bir ideal' yetiştirme sistemi olmadığı, sistemlerin kendi içlerinde $d_{1}$ ș ve iç kalite özelliklerini etkileyecek avantaj/dezavantajlarının bulunabildiği belirlendi.
\end{abstract}

\section{Quality traits of retail eggs produced by alternative and cage rearing systems}

\begin{abstract}
:
This study, which was conducted to determine the compliance of outer and inner quality traits of retail brown and white grade A table eggs with respect to Turkish Egg Regulation and Standard, a total of 350 eggs comprised of 200 brown (50 from each system), and 150 white (each 50, except free-range) produced by alternative (organic, free-range and barn) and cage systems, were analyzed. Effect of rearing system was statistically significant in brown eggs for shape index, shell weight, shell strength and Haugh Unit (HU), and in white eggs for all outer and inner quality traits except shape index, shell thickness and air cell height $(\mathrm{p}<0.05)$. All samples complied with the egg weight requirements, while air cell height of free-range brown eggs was found higher $(6.75 \mathrm{~mm})$, thus non-compliant than the indicated upper limit indicated in Turkish Food Codex Egg Directive 2014/55. Cage system white eggs' HU values were in compliance with the Turkish Standard for Chicken Egg - in Shell (TS1068), while this value was lower than the required limits in freerange and cage brown eggs. Cage brown eggs had higher shape index (\%79-spherical), while white eggs had lower shell weight $(7.26 \mathrm{~g})$; free-range and cage brown eggs had thicker shells $(0.32 \mathrm{~mm})$, and organic white and cage brown eggs had the strongest shell; the darkest and the faintest yellow were in cage white and organic eggs, respectively. In conclusion, there is no 'one ideal' rearing system to produce eggs compliant to all quality traits, and thus the systems can have advantages/disadvantages effecting outer and inner quality of eggs.
\end{abstract}

How to cite this article: Tekin Eİ, Çetin E, Temelli S, Eyigör A: Alternatif ve kafes yetiştirme sistemleri ile üretilen perakende yumurtaların kalite özellikleri. Vet Hekim Der Derg, 90 (2): 143-151, 2019. DOI: 10.33188/vetheder.540604

* Sorumlu yazar/Corresponding author

eposta adresi/e-mail address: aeyigor@uludag.edu.tr 


\section{Giriş}

Dünya yumurta üretiminde 1.205.075 ton ile 8. sırada yer alan ülkemizde (7), yumurta tavukçuluğunda halen yaygın olarak kafes sistemi kullanılmaktadır. Ancak Avrupa Birliği (AB) ülkelerinde hayvan refahı ve sağlığı konularında duyulan hassasiyet nedeni ile 2012 yılından itibaren kafes sistemi yerine zenginleştirilmiş kafes veya alternatif yetiştirme sistemlerinin kullanımına geçilmiştir. 2017 yılı verilerine göre, AB'de yumurta tavukçuluğu işletmelerinde kullanılan sistemlerin payı; zenginleştirilmiş kafes \% 53.2, kümes \% 26.5, serbest dolaşım \% 15.3 ve organik \% 5.1 olarak belirtilmiştir (30).

Benzer şekilde ülkemizde, 1999/74/EC sayılı 'Yumurtacı Tavukların Korunması ile İlgili Asgari Standartları Belirleyen Avrupa Birliği Konsey Direktifi'ne ve 2002/4 sayılı 'Yumurtacı Tavuk İşletmelerinin Kayıt Altına Alınmasına İlişkin Avrupa Birliği Komisyon Direktifi'ne paralel olarak hazırlanmış 'Yumurtacı Tavukların Korunması ile İlgili Asgari Standartlara İlişkin Yönetmelik’ 22 Kasım 2014 tarih ve 29183 sayılı Resmi Gazete (17)’ de yayımlanarak yürürlüğe girmiştir. Bu yönetmeliğin ikinci bölümünde yetiştirme sistemleri; (a) alternatif sistemler, (b) zenginleştirilmemiş kafes sistemleri ve (c) zenginleştirilmiş kafes sistemleri olarak sınıflandırılmış, bu sistemler için uygulanacak gerekliliklere ayrı ayrı yer verilmiştir. Ayrıca, uyum zorunluğuna ilişkin geçici madde 1'de çalışmakta olan mevcut işletmelerde, zenginleştirilmemiş kafes sistemlerinin 1 Ocak 2023 tarihinden itibaren kullanılmayacağı bildirilmiştir.

2014 yılından itibaren yürürlükte olan 'Türk Gıda Kodeksi Yumurta Tebliği 2014/55 (Yumurta Tebliği) ile ilgili 24 Kasım 2017 tarih ve 30250 sayılı Resmi Gazete (18)'de yapılan revizyonda, etiketleme ve işaretlemeye ait madde 12'de A sınıfi yumurtada yetiştirme metodu kodunun yumurta kabuğu üzerine damgalanması zorunluluğu getirilmiştir. Yetiştirme metodunun tespiti hususunda ise 'Yumurtacı Tavukların Korunması ile İlgili Asgari Standartlara İlişkin Yönetmelik’ (17) hükümlerinin esas alınacağı, yetiştirme metodu kodu, işletme ve kümes numarası önüne, organik yetiştiricilik için 0, free-range (açık dolaşıma erişim) yetiştiricilik için 1, kümeste kafessiz yetiştiricilik için 2 ve kafesli yetiştiricilik için 3 olacak şekilde yumurta kabuğuna damgalanacağı bildirilmiştir. Ayrıca, yetiştirme metodu kodu, işletme ve kümes numarası yazılmamış olan A sınıfı yumurtaların, toptan veya perakende olarak satışa arz edilemeyeceği, yetiştirme sistemi kodunun A sınıfı yumurtaların etiket bilgisinde de açık olarak yazılacağı ve konu ile ilgili olarak gıda işletmecilerinin 16 Nisan 2018 tarihine kadar bu Tebliğ hükümlerine uyum sağlamak zorunda olduğu belirtilmiştir.

Perakende satışa sunulan yumurtalar, üretim sistemi, tavuğun $1 \mathrm{rk1}$, yaşı ve beslenme durumuna bakılmaksızın, fizikokimyasal ve mikrobiyal kalite yönünden yasal gerekliliklere uygun olarak tüketiciye sunulmalıdır. Ülkemizde A sınıfi yumurta kalitesinin (dış ve iç) belirlenmesinde; yumurtanın Yumurta Tebliği (18) 'ne göre ağırlık, hava boşluğu yüksekliği, kabuk temizliği ve bütünlüğü, ak ve sarının durumu yönünden ve Türk Standardı Tavuk Yumurtası-Kabuklu (TS1068) (25)'na göre ise duyusal, fiziksel (hava boşluğu yüksekliği, Haugh Birimi-HB) ve boy özellikleri açısından incelenmesi gerektiği belirtilmiştir.

Yumurta kalitesi ile ilgili olarak üretimde kullanılan yetiştirme sistemlerine bağlı olarak üretim aşamasında çiftliklerden elde edilen yumurtalarda 1 rk, yaş, besleme durumu gibi önemli faktörlerin diş ve iç kalite özelliklerine üzerine etkisinin incelendiği oldukça fazla araştırma bulunmaktadır $(1,9,11,14,20,21,24,26$, 29). Bununla birlikte, perakende işletmelerde satışa sunulan yumurtalarda, farklı üretim sistemlerine ait yumurtaların yasal gereklilikler çerçevesinde belirtilen kalite özelliklerinin belirlenmesi konusundaki çalışma sayısının bilgimiz dahilinde az olduğu $(3,10)$, ülkemiz için yeni, büyüyen ve tüketici talebinin giderek arttığı alternatif sistemlerden olan organik ve kümeste üretilen yumurtalarda, konu ile ilgili bir veri bulunmadığı görülmektedir. Bu nedenle, çalışmamızda, organik, serbest dolaşım, kümes ve geleneksel kafes yetiştiriciliğine ait perakende satışa sunulan yumurtaların kalite özelliklerinin belirlenmesi ve Yumurta Tebliği ile Yumurta Standardı'na uyumluluğunun değerlendirilmesi amaçlanmiştır. 


\section{Gereç ve Yöntem}

Çalışmada, Şubat 2018 - Haziran 2018 tarihleri arasındaki 5 aylık süre içerisinde Kocaeli ve Bursa'da perakende ve orijinal ambalajlı olarak satışa sunulan, etiket bilgisi üzerinde genotip, yaş ve beslenme hakkında bilgi verilmeyen 21 farklı firmaya ait (5 organik, 3 serbest dolaşım, 4 kümes, 9 kafes) orta ağırlıkta (M), A sinıfi 200 kahverengi (her bir sistemden 50 adet), 150 beyaz (serbest dolaşım hariç her bir sistemden 50 adet) olmak üzere toplam 350 adet tavuk yumurtası örnek olarak kullanıldı. Yumurta Tebliği (18)'nin madde 12 (a) bendinde yer alan yetiştirme sistemlerinin numaralandırılmasına göre organik (0), serbest dolaşım (1), kümes (2) ve kafes (3) olarak 4 gruba ayrılan kahverengi yumurtalar ile; serbest dolaşım beyaz tavuk yumurtasının perakende işletmelerde mevcut olmaması nedeni organik (0), kümes (2) ve kafes (3) olmak üzere 3 gruba ayrılan beyaz yumurtalar satın alınarak çalışma güvenilirliği için hareket etmeyecek ve soğuk zincir bozulmayacak şekilde laboratuvara taşınıp 1 gece buzdolabı sıcaklığında muhafaza edildikten sonra analiz edildi.

\section{Yumurta dıș kalite özelliklerinin incelenmesi}

Yumurta ağırlığının belirlenmesinde, yumurtalar 0.0001 hassasiyetli terazide (Laboratory Scale, Sartorius, BA2010S, Germany) darası alındıktan sonra tartılarak ağırlıkları (g) alındı ve kaydedildi. Ölçülen ağırlıkların tümü Yumurta Tebliği (18) Ek-2'de yer alan A kalite yumurtanın ağırlık sınıfları tablosuna göre M yumurta için verilen 53$63 \mathrm{~g}$ aralı̆̆ göz önünde bulundurularak değerlendirildi.

Şekil indeksi değeri, öncelikle her bir yumurtanın eni ve boyu, yumurtanın en geniş ve en uzun noktalarının dijital kumpasa (Caliper, Mitutoyo Code No. 500-181-20, Model CD-15CPX, Japan) yerleştirilerek ölçülmesi ve sonrasında bu iki değerin, 'Şekil indeksi = yumurta genişliği $(\mathrm{mm}) /$ yumurta uzunluğu $(\mathrm{mm})$ x 100' formülünde kullanılarak hesaplandı. Şekil indeksi standartlarına göre; \% 74 ideal, $<\% 72$ uzun ve $>\% 76$ ise küresel yumurta olarak değerlendirildi (12).

Yumurtaların kabuk ağırlığı, 0.0001 hassasiyetli terazide (Laboratory Scale, Sartorius, BA2010S, Germany) darası alındıktan sonra tartılarak ağırlıkları $(\mathrm{g})$ sabit bir okuma görüldüğünde okundu ve kaydedildi.

Kabuk kalınlığının belirlenmesinde, yumurtanın iki uç ve orta kısımlarından birer parça olmak üzere, üç ayrı parçanın diş ve iç zarları soyulduktan sonra her biri dijital kumpasa (Caliper, Mitutoyo Code No. 500-181-20, Model CD-15CPX, Japan) yerleştirilerek ölçüldü ve okunan değer $(\mathrm{mm})$ kaydedildi. Ortalama kabuk kalınlığı ise bu üç değerin aritmetik ortalamasının alınması ile bulundu.

Yumurtaların kabuk kırılma direncinin saptanması amacı ile, her bir yumurta dik olarak ve küt ucu yukarı gelecek şekilde bir kap içerisinde kabuk kırılma direnci ölçüm cihazına (Push Pull Scale, Imada, Model No. SV-05, Japan) yerleştirildi. Daha sonra cihazın üst mengenesi aşağı doğru kaydırılarak mengene ile yumurta arasında hiç boşluk kalmayacak şekilde sıkıştırıldı. Mengene bu noktadan sonra yumurtanın kırılma noktasına kadar yavaşça daha da aşağı itildi ve kırılma noktasında skalada okunan değer Newton $/ \mathrm{cm}^{2}\left(\mathrm{~N} / \mathrm{cm}^{2}\right)$ olarak kaydedildi (4).

\section{Yumurta iç kalite özelliklerinin incelenmesi}

Her bir yumurtada var olan hava boşluğu yüksekliğinin ölçümü için yumurtalar karanlık odada lamba kontrolü altında hava kesesinin en tepe noktası ile boşluğun kabuğa değdiği noktadan geçen sanal düzlemde bu iki noktanın birbirine en uzak olduğu noktadan cetvel yardımı ile ölçüldü ve okunan değer kaydedildi. Ölçüm sonuçları TS1068 (25) gerekliliklerine göre (ekstra taze $\leq 4 \mathrm{~mm}$, ekstra taze dış1 $\leq 6 \mathrm{~mm}$, sabit olmalı) ve Yumurta Tebliği (18)'nde belirtilen A sınıfı yumurtanın kalite özellikleri (hava boşluğu yüksekliği ekstra taze olarak satışa sunulan yumurtada $4 \mathrm{~mm}$, diğerlerinde $6 \mathrm{~mm}$ 'den yüksek olmamalı ve sabit olmalıdır) göz önünde bulundurularak değerlendirildi.

Ak indeksinin saptanmasında, öncelikle her bir yumurta cam bir tabla üzerine dağılmadan kırıldıktan sonra, dijital kumpas (Caliper, Mitutoyo Code No. 500-181-20, Model CD-15CPX, Japan) ile ak genişliği ve ak uzunluğu, üç ayaklı mikrometre ile de ak yüksekliği $(\mathrm{H}$, diş koyu ak yüksekliği) ölçülerek kaydedildikten sonra Ak indeksi = (ak yüksekliği $(\mathrm{mm})$ / uzunluk ve genişliğin ortalaması $(\mathrm{mm})$ ) x 100 formülüne göre hesaplandı. Sonuçlar A sınıfi bir yumurtanın taşıması gereken ortalama \% 3.8-6.7 ak indeksi değer aralığı göz önünde bulundurularak değerlendirildi 
(2).

Yumurtalarda HB hesaplanması için yumurta ağırlığı-g $(\mathrm{G})$ ve ak yüksekliği-mm $(\mathrm{H}) \mathrm{HB}=100 \log (\mathrm{H}+$ $7.57-1.70 \mathrm{G}^{0.37}$ ) formülü (23) kullanılarak hesaplandıktan sonra TS1068 (25) A sinıfi yumurta gerekliliklerine göre (ekstra taze $\geq 72$, ekstra taze diş1 71-51) değerlendirildi.

Sarı kalitesinin belirlenmesinde sarı indeksinin hesaplanması için öncelikle sarı yüksekliği ve sarı genişliği, her bir yumurtanın cam bir tabla üzerine dağılmadan kırıldıktan sonra dijital kumpas (Caliper, Mitutoyo Code No. 500-181-20, Model CD-15CPX, Japan) ile ölçüldü ve kaydedildi. Hesaplama, Sarı indeksi = sarı yüksekliği (mm) / sarı genişliği (mm) x 100 formülü kullanılarak yapıldı.

Yumurta sarısının renginin ölçülmesinde, 15 dilimden oluşan Roche skalası kullanıldı (DSM, 2005-HMB, 51548, Switzerland).

\section{İstatistiksel analizler}

Tüm veriler SPSS 22.0 programı (IBM Corp. 2013. IBM SPSS Statistics for Windows, Version 22.0. Armonk, NY: IBM Corp.) (22) kullanılarak analiz edildi. Farklı yetiştirme sistemlerinden alınan perakendekahverengi ve beyaz yumurtaların dış ve iç kalite özelliklerine ait ortalama ve standart sapma değerleri tablolar halinde verildi. Yumurtanın dış ve iç kalite özellikleri üzerine yetiştirme sistemlerinin etkisini incelemek amacıyla Tek Yönlü Varyans Analizi (One Way Analysis of Variance - ANOVA) uygulandı. Dağılımın homojen olduğu durumlarda post-test olarak Tukey'in Çoklu Karşılaştırma testi yapıldı. Analizlerin tümünde önem derecesi olarak $\mathrm{p}<0.05$ değeri kullanıldı.

\section{Bulgular}

Farklı yetiştirme sistemlerine ait perakende kahverengi ve beyaz yumurtalardaki dış ve iç kalite özellikleri sırasıyla Tablo 1 ve Tablo 2'de sunulmuştur.

Tablo 1: Farklı yetiştirme sistemlerine ait perakende kahverengi yumurtalardaki dış ve iç kalite özellikleri

Table 1: Outer and inner quality traits of retail brown eggs of different rearing systems

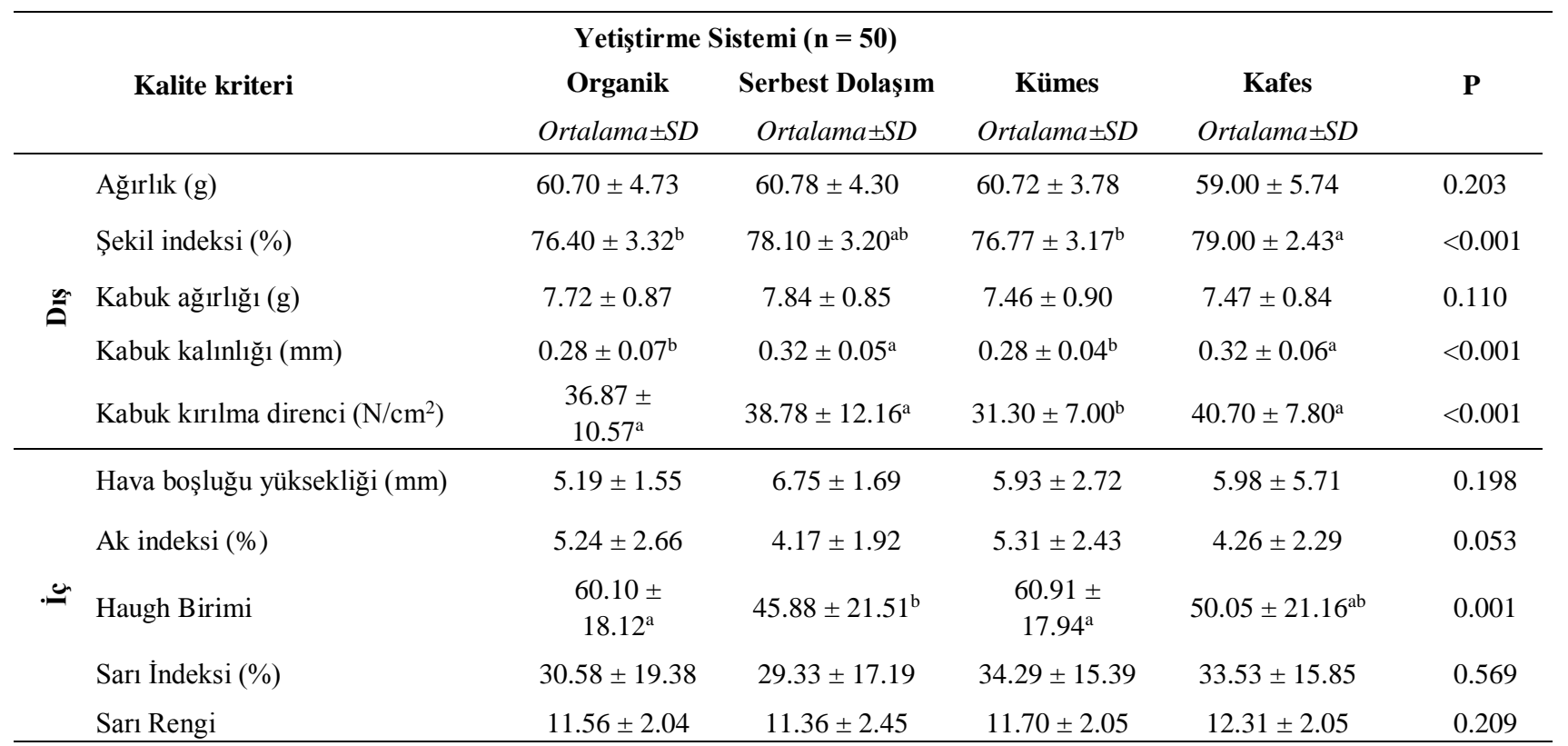

SD: Standart Sapma, ${ }^{a, b, a b}$ : Aynı satırda farkl harflerle gösterilen değerler arasındaki farklllk $p<0.05$ düzeyinde önemlidir.

$S D$ : Standard Deviation, ${ }^{a, b},{ }^{a b}$ : Values in the same row with different superscript are significantly different at $p<0.05$. 
Tablo 2: Farklı yetiştirme sistemlerine ait perakende beyaz yumurtalardaki dış ve iç kalite özellikleri Table 2: Outer and inner quality traits of retail white eggs of different rearing systems

\begin{tabular}{|c|c|c|c|c|}
\hline \multirow[b]{2}{*}{ Kalite kriteri } & \multicolumn{3}{|c|}{ Yetiştirme Metodu $(\mathbf{n}=\mathbf{5 0})$} & \multirow{3}{*}{$\mathbf{P}$} \\
\hline & Organik & Kümes & Kafes & \\
\hline$\underline{\underline{\text { Dis }}}$ & Ortalama \pm SD & Ortalama \pm SD & Ortalama \pm SD & \\
\hline Ağırlık (g) & $64.13 \pm 3.39^{\mathrm{a}}$ & $62.44 \pm 4.01^{\mathrm{a}}$ & $57.94 \pm 4.80^{\mathrm{b}}$ & $<0.001$ \\
\hline Şekil indeksi (\%) & $75.81 \pm 2.69$ & $76.33 \pm 2.59$ & $76.40 \pm 2.71$ & 0.554 \\
\hline Kabuk ağırlı̆̆ı $(g)$ & $8.45 \pm 0.64^{\mathrm{a}}$ & $8.07 \pm 0.82^{\mathrm{a}}$ & $7.26 \pm 0.76^{\mathrm{b}}$ & $<0.001$ \\
\hline Kabuk kalınlığı (mm) & $0.29 \pm 0.04$ & $0.31 \pm 0.05$ & $0.31 \pm 0.08$ & 0.346 \\
\hline Kabuk kırılma direnci $\left(\mathrm{N} / \mathrm{cm}^{2}\right)$ & $46.52 \pm 4.11^{\mathrm{a}}$ & $38.10 \pm 7.84^{b}$ & $37.58 \pm 9.02^{\mathrm{b}}$ & $<0.001$ \\
\hline \multicolumn{5}{|l|}{$\underline{\text { Icc }}$} \\
\hline Hava boşluğu yüksekliği (mm) & $4.60 \pm 1.03$ & $4.10 \pm 1.30$ & $4.13 \pm 1.67$ & 0.189 \\
\hline Ak indeksi (\%) & $4.82 \pm 1.16^{\mathrm{b}}$ & $5.18 \pm 1.17^{b}$ & $5.96 \pm 1.60^{\mathrm{a}}$ & 0.001 \\
\hline Haugh Birimi & $63.38 \pm 12.61^{\mathrm{b}}$ & $67.65 \pm 11.57^{\mathrm{b}}$ & $75.71 \pm 11.00^{\mathrm{a}}$ & $<0.001$ \\
\hline Sarı İndeksi (\%) & $34.54 \pm 13.02^{\mathrm{b}}$ & $41.11 \pm 3.95^{\mathrm{a}}$ & $42.75 \pm 5.67^{\mathrm{a}}$ & $<0.001$ \\
\hline Sarı Rengi & $9.55 \pm 1.43^{\mathrm{b}}$ & $10.70 \pm 1.92^{\mathrm{a}}$ & $11.40 \pm 2.70^{\mathrm{a}}$ & $<0.001$ \\
\hline
\end{tabular}

SD: Standart Sapma, ${ }^{a, b}$ : Aynı satırda farkl harflerle gösterilen değerler arasindaki farklllık $p<0.05$ düzeyinde önemlidir.

SD: Standard Deviation, ${ }^{a, b}$ : Values in the same row with different superscript are significantly different at $p<0.05$.

\section{Tartışma ve Sonuç}

Günümüz yumurta endüstrisinde, ürün kalitesi için standart ve süreklilik arz eden bir model benimsenmektedir. Kaliteyi yumurtlamadan önce etkileyen genetik altyapı, yaş, beslenme, hastalık durumu, sürü yönetim uygulamaları gibi faktörlerin yanı sıra yumurtlama sonrasında ürünün toplama, sinıflandırma, depolama, nakliye, perakende ve pazarlama koşulları da kalitede devamlılığı ve pazarlamaya elverişliliği sağlamaktadır (26).

Tüketici açısından en önemli kalite özelliklerinden biri olan yumurta ağırlığının birim fiyat belirlenmesinde 'kg başına ağırlık' uygulaması tercih edilmektedir. Genellikle tüketicilerin alışkın olduğu M yumurta ağırlığı olup aşırı büyük yumurtalar (> $70 \mathrm{~g}$ ) kabuğun incelmesi nedeni ile kırılma tehlikesi, ambalajlamada zorluk veya özel ambalaj için ilave masraf gerektirmesine bağlı olarak tercih edilmemektedir. Çalışmamızda, incelenen kahverengi ve beyaz yumurta ağırlıkları sırasıyla 59.00 - $60.78 \mathrm{~g}$ ve 57.94 - $64.13 \mathrm{~g}$ (Tablo 1 ve 2) aralığında olup, tüm yumurtaların Yumurta Tebliği (18)'nde M ağırlık sınıfındaki perakende A sınıfı yumurtalar için verilen 53-63 g aralığına ve ağırlık kontrolüne dair tolerans değerlerine uygun olduğu saptanmıştır. Kahverengi ve beyaz yumurtalarda en düşük ağırlığa kafes sisteminde rastlanılmış, yetiştirme sistemlerinin ağırlı üzerine etkisinin kahverengi yumurtalarda önemli bulunmazken beyaz yumurtalarda $\mathrm{p}<0.05$ düzeyinde önemli olduğu tespit edilmiştir (Tablo 2). Bulgumuza paralel olarak, Golden ve ark. (9) ve Rehman ve ark. (16) kahverengi yumurtalarda yetiştirme sistemlerinin ağırlık üzerine etkisinin olmadığını, Dukic-Stojcic ve ark. (6), Pistekova ve ark. (15) ile Varguez-Montero ve ark. (29) ise önemli etkisinin olduğunu rapor etmiştir. Jones ve ark. (11)’nın kümes, kafes ve zenginleştirilmiş kafes sistemi ile üretilen beyaz yumurtaların kalitelerini inceledikleri çalışmalarında, en düşük yumurta ağırlığının kafes sistemine ait olduğu belirtilmiştir. Benzer olarak çalışmamızda da, kafes sistemine ait yumurtaların organik ve kümes yumurtalarına kıyasla daha hafif olduğu saptanmıştır. Perakende yumurtalarda, yumurta ağırlığına ait elde edilen bu sonuçların, özellikle yumurtlamanın farklı dönemlerindeki farklı ırklara ait olma olasılı̆̆ına bağlanmaktadır. Bunun yanında, yem içeriği ve tüketim miktarı ile sıcaklık gibi çevresel etkenlerin de bu özellik üzerinde etkili olabileceği düşünülmektedir.

İdeal bir yumurtanın şekil indeksi değeri \% 74 olarak kabul edilmektedir. Çalışmada, kahverengi 
yumurtalarda kafes sisteminin organik ve kümes sistemlerinden alınanlara kıyasla daha yüksek şekil indeksi değerine (\% 79.00), dolayısı ile daha küresel bir görünüme sahip olduğu belirlenmiştir ( $p<0.005)$ (Tablo 1). Ayrıca, beyaz yumurtalarda yetiştirme sistemlerinin şekil indeksi üzerine etkisi olmadığ saptanmıştır. Şekil indeksi üzerine yetiştirme sistemlerinin etkisinin olduğunu $(10,13,20,21,24,28)$ ve olmadığını $(1,5,6,16)$ rapor eden araştırmalar bulunmaktadır.

Yumurta kabuk kalitesinin belirlenmesinde kabuk ağırlığı, kabuk kalınlığı ve kabuk kırılma direnci değerleri özellikle yumurtaların toplanması, sınıflandırılması, paketlenmesi, depolanması, nakli aşamalarında çatlama ve kırılmalara bağlı olarak oluşabilecek ekonomik kayıpların önlenmesi yönünden endüstride ve pazarlamada önemli göstergelerdir (27). Yumurta kabuk kalitesi, birincil olarak genetik yapıya ve yaşa bağlı olup, ayrıca yemle alınan kalsiyum, fosfor, potasyum, mangan ve bakır minerallerinin miktarına, hastalık ve kullanılan ilaçlara göre değişmektedir (26). Bunun yanında, yetiştirme sistemlerinin de etkisi olduğu, özellikle yumurtlamanın son dönemleri göz önünde bulundurulduğunda, tavukların daha hareketli olduğu sistemlerde kalsiyum metabolizmasının aktive olması ile göreceli olarak daha ağır kabuklu yumurta üretebildikleri rapor edilmiştir (19). Benzer şekilde çalışmamızda, beyaz yumurtalar içerisinde kafes sistemi ile üretilmiş olanların kabuklarının organik ve kümes yumurtalarının kabuklarına oranla daha hafif olduğu tespit edilmiştir $(\mathrm{p}<0.05$ ) (Tablo 2). Bununla birlikte, kahverengi perakende yumurtalarda, sistemler arası istatistiksel öneme sahip bir kabuk ağırlık farkı bulunmaması Şekeroğlu ve Sarıca (24) ile Varguez-Montero ve ark. (29) ile uyumlu iken, organik ve kümes sistemlerinden elde ettikleri kahverengi yumurtalarda kabuk ağırlı̆̆ yönünden istatistiksel fark bulan Ferrante ve ark. (8) ve Sokolowicz ve ark. (20) ile uyum göstermemektedir. Kahverengi yumurtalarda, serbest dolaşım ve kafes yumurtalarının kabuk kalınlıkları ortalama $0.32 \mathrm{~mm}$ iken organik ve kümes yumurtalarının $0.28 \mathrm{~mm}$ ile istatistiksel olarak önemli $(\mathrm{p}<0.05)$ derecede daha ince olduğu saptanmıştır (Tablo 1 ve 2). Dukic-Stojcic ve ark. (6) ile Petek ve ark. (14)' nın serbest dolaşımın kafes sistemine göre ve Varguez-Montero ve ark. (29)'nın kümes sisteminin serbest dolaşım ve kafes sistemine göre daha kalın yumurta kabuğuna sahip olduğunu belirttikleri çalışmaları ile bulgularımız uyum göstermemektedir. Çalışmamızda, beyaz yumurtalarda, sistemler arasında kabuk kalınlığı yönünden önemli bir fark bulunmamıştır. En yüksek kabuk kırılma direncinin beyaz yumurtalarda organik sisteme $\left(48.52 \mathrm{~N} / \mathrm{cm}^{2}\right)$, kahverengi yumurtalarda ise beklenenin aksine kafes sistemine $\left(40.70 \mathrm{~N} / \mathrm{cm}^{2}\right)$ ait olduğu bulunmuştur (Tablo 1 ve 2). Benzer şekilde, beyaz yumurtalarda kafes sisteminden elde edilenlerin kabuk kırılma direncinin yüksek olduğunu bildiren çalışmalar bulunmaktadır (10,11). Ahammed ve ark. (1), Artan ve Durmuş (3) ile Golden ve ark. (9) yetiştirme sistemlerinin bu kalite özelliği üzerine olan etkisinin önemli, Dukic-Stojcic ve ark. (6), Pistekova ve ark. (15), Sokolowicz ve ark. (20), Şekeroğlu ve Sarıca (24) ise önemli olmadığını bildirmişlerdir. Ülkemizde, Yumurta Tebliği (18) ve TS1068 (25)'de kabuk kalitesi ile ilgili herhangi bir sınır değer bulunmamakla birlikte, endüstride A sınıfı perakende yumurtaların kabuk kalınlığının 0.20-0.40 mm, kabuk kırılma direncinin ise 30-40 N/ $\mathrm{cm}^{2}$ aralığında olması istenmektedir. Çalışmada, incelenen tüm yumurta örneklerinin bu değer aralıklarında olduğu belirlenmiştir.

Yumurtanın iç kalite özellikleri içerisinde yer alan hava boşluğu yüksekliği, endüstride raf ömrünün, tüketiciler için ise taze/bayat olup olmadığının belirlenmesinde kullanılmaktadır (27). Hava boşluğu yüksekliğindeki artış, depolama süresi kadar deponun sıcaklığı, rutubeti ve hava sirkülasyonu ile de yakından ilişkilidir (2). Çalışmamızda, kahverengi yumurtaların hava boşluğu yüksekliğinin 5.19-6.75 mm ile beyazlara (4.10-4.60 mm) göre daha fazla olduğu ancak bu farkın istatistiksel olarak önemli bulunmadığı belirlenmiştir (Tablo 1 ve 2). Bulgularımızın aksine yetiştirme sistemlerinin hava boşluğu yüksekliği üzerine etkisinin önemli olduğu Artan ve Durmuş (3) ile Hidalgo ve ark. (10) tarafindan bildirilmiştir. Yumurta Tebliği (18)'ne göre A sınıfi perakende yumurtaların hava boşluğu yüksekliğinin $6 \mathrm{~mm}$ 'den fazla olmaması gerekmektedir. Serbest dolaşım sistemi ile yetiştirilen tavuklara ait kahverengi yumurtalarda bulunan hava boşluğu yüksekliğinin ortalama $6.75 \mathrm{~mm}$ olup ilgili Tebliğ (18)'e uygun olmadığı, B sinıfi yumurta kalitesinde olduğu görülmektedir. Ayrıca, en fazla hava boşluğu yüksekliğine sahip bu yumurtalarda, beklenildiği gibi en düşük ak indeksi değerinin (\% 4.17) de tespit edilmesi (Tablo 1), Artan ve Durmuş (3)'un bulgusu ile uyum göstermemektedir. Bunun yanı sıra, beyaz yumurtalarda kafes sisteminin (\% 5.96), organik ve kümes sistemlerine göre daha yüksek ak indeksi değerine sahip ve buna bağlı olarak yetiştirme sistemlerinin ak indeksi değeri üzerine etkisinin önemli $(\mathrm{p}<005)$ düzeyde olduğu belirlenmiştir (Tablo 2).

İç kalitenin belirlenmesinde en önemli özelliklerden bir diğeri olan HB değeri ile ilgili olarak TS1068 
(25)'de A sınıfı yumurtalarda 51-71 aralığında olması gerektiği belirtilmektedir. Çalışmamızda, kafes sistemi ile elde edilen beyaz yumurtaların HB değeri organik ve kümes yumurtalarına göre daha yüksek $(\mathrm{p}<0.05)$ ve ortalama 75.71 olup ekstra taze yumurta özelliği taşıdığı görülmüştür (Tablo 2). Bunun yanı sira kahverengi yumurtalarda, serbest dolaşım (45.88) ve kafes (50.05) sistemlerinden alınanların HB ortalamalarının bu aralığın altında kalarak diğer sistemlerden istatistiksel olarak farklı olduğu $(\mathrm{p}<0.05)$ ve ayrıca TS1068 (25) gerekliliklerine uymayıp, bu yönden B sınıfi yumurta kalitesinde olduğu saptanmıştır (Tablo 1). Bulgularımıza paralel olarak renk farkı gözetmeksizin HB üzerine sistemlerin etkisinin önemli olduğunu bildiren çalışmalar $(1,3,6,9,10,11,24)$ çoğunlukta olup, önem bulunmadığını rapor eden araştırmalar $(16,21,29)$ da bulunmaktadır.

Organik beyaz yumurtaların en düşük sarı indeksi değerine sahip olduğu ve yetiştirme sistemlerinin bu özellik üzerine etkili $(\mathrm{p}<0.05)$ olduğu bulunmuştur. Bunun aksine bulgularımıza paralel olarak Rehman ve ark. (16) ile Şekeroğlu ve Sarıca (24) kahverengi yumurtalarda sistemin etkisinin olmadığını saptamışlardır. Yumurta sarısının rengi, gida endüstrisi ve tüketiciler için önem taşımakta olup, ülkemizde genellikle renk skoru 12-13 olan yumurtalar tercih edilmektedir. Çalışmamızda, kahverengi yumurtaların beyazlara kıyasla daha koyu sarı renkte olduğu, beyaz yumurtalarda ise kafes sistemine ait yumurtaların en koyu sarı renge (11.40) sahip iken organik sisteme ait yumurtaların sarı renginin en açık (9.55) olduğu belirlenmiştir (Tablo 1 ve 2). Kafes sisteminde üretilen yumurtaların daha koyu sarı rengine sahip olduğunu belirten Hidalgo ve ark. (10) ile bu bulgumuz örtüşmektedir. Bunun yanı sıra, kahverengi yumurtalarda yetiştirme sisteminin sarı rengi üzerine etkisinin önemsiz olduğu bulunmuş olup bulgularımızın aksine kahverengi yumurtalarda serbest dolaşım sisteminin sarı rengine etkisinin önemli olduğunu rapor eden çalışmalar $(3,14,24)$ ile uyum göstermemektedir.

Çalışmamızda, organik, serbest dolaşım, kümes ve geleneksel kafes sistemleri ile üretilip perakende satışa sunulan ve gerek bulundukları ambalaj üzerindeki etiket bilgilerinde gerekse herbir yumurta kabuğu üzerindeki damgada genotip, yaş ve beslenme hakkında bilgi verilmeyen yumurtaların, Yumurta Tebliği ile Yumurta Standardı'nda belirtilen kalite özellikleri yönünden değerlendirilmesi amaçlanmıştır. Satın alınan bu yumurtaların, ait olduğu tavukların genetik alt yapıları (ırk), yaşları (tavukların yumurtlamanın kaçıncı haftasında oldukları), sistemlerde kullanılan yemlerin özellikleri ve besleme yöntemleri hakkında bilgi olmaması, bu çalışmanın kısıtlılığını oluşturmaktadır. Bu faktörlere bağlı değişiklikler ile çalışmanın tekrar edilmesi durumunda, farklı sonuçlar elde edilebileceği göz önünde bulundurulmalıdır. Söz konusu özelliklerin etkisi göz önünde bulundurulmaksızın, piyasaya arz aşamasındaki yumurtaların kalite durumlarının tespitine yönelik olarak gerçekleştirilen çalışma, ülkemizde perakende yumurtalarda kalite özelliklerinin incelendiği az sayıdaki çalışmalar ile birlikte bu konuda yeni bir veri oluşturması açısından önem taşımaktadır. Bununla birlikte, tek bir yetiştirme sisteminin bir diğerine üstün olması gibi kesin bir yargının olamayacağını, her sistemin kendi içerisinde farklı kalite özellikleri yönünden bir diğerine göre avantaj ve/veya dezavantajlarının bulunabileceğini göstermektedir. Ayrıca, hayvan refahı gereklilikleri kapsamında oluşturulan alternatif yetiştirme sistemleri ile yumurtacı tavukların yaşam kalitelerinin kontrol altında bulundurulması amaçlanmış olup, bu durum bu tip sistemlerdeki tavukların her yönden daha sağlıklı, elde edilen yumurtaların ise diş ve iç kalite özelliklerinin geleneksel kafes sistemine göre daha üstün olacağ 1 anlamına gelmemektedir. Perakende yumurta kalitesinde, sadece yetiştirme sisteminin değil aynı zamanda depolama, nakil, perakende uygulamaları, ürün geri çekme/çağırma ve satışa kadarki geçen zaman gibi direkt olarak üretim sistemine bağlı olmayan ancak kaliteyi önemli derecede etkileyebilecek diğer faktörlerin de varlı̆̆ının bu konuda yapılacak çalışmalara yön vermesi açısından değerlendirilmesi gerekmektedir.

\section{Kaynaklar}

1. Ahammed M, Chae BJ, Lohakare J, Keohavong B, Lee MH, Lee SJ, Kim DM, Lee JY, Ohh SJ (2014): Comparison of aviary, barn and conventional cage raising of chickens on laying performance and egg quality. Asian-Aust J Anim Sci, 27, 1196-1203.

2. Anar Ş (2016): Yumurta ve Yumurta Ürünleri. 1. Bask1, Dora Basım-Yayın Dağıtım Ltd. Şti., Bursa.

3. Artan S, Durmuş İ (2015): Köy, serbest ve kafes sistemlerinde üretilen yumurtaların kalite özellikleri bakımından karşılaştırılması. Academic J Agric, 4, 89-97. 
4. Balnave D, Muheereza SK (1997): Improving eggshell quality at high temperatures with dietary sodium bicarbonate. Poult Sci, 76, 588-593.

5. Çetin E, Temelli S, Eyigör A (2016): Effect of rearing systems and shell color on some egg quality parameters. Uludag Univ J Fac Vet Med, 35, 11-16.

6. Dukic-Stojcic M, Peric L, Bjedov S, Milosevic N (2009): The quality of table eggs produced in different housing systems. Biotechnol Anim Husb, 25, 1103-1108.

7. FAO (2017): Food and Agricultural Organization of the United Nations. FAOSTAT Livestock Primary, Egg in Shell Production. Erişim Tarihi: 11.03.2019, Erişim Linki: http://www.fao.org/faostat/en/\#data/QL

8. Ferrante V, Lolli S, Vezzoli G, Cavalchini LG (2009): Effects of two different rearing systems (organic and barn) on production performance, animal welfare traits and egg quality characteristics in laying hens. Ital J Anim Sci, 8, 165-174.

9. Golden JB, Arbona DV, Anderson, KE (2012): A comparative examination of rearing parameters and layer production performance for brown egg-type pullets grown for either free-range or cage production. $\mathrm{J}$ Appl Poult Res, 21, 95-102.

10. Hidalgo A, Rossi M, Clerici F, Ratti S (2008): A market study on the quality characteristics of eggs from different housing systems. Food Chem, 106, 1031-1038.

11. Jones DR, Karcher DM, Abdo Z (2014): Effect of a commercial housing system on egg quality during extended storage. Poult Sci, 93, 1282-1288.

12. Khalafalla MK, Bessei W (1995): Reliability of quasi-static compression as an indicator of eggshell quality. In: Proceedings of the $6^{\text {th }}$ European Symposium on the Quality of Egg and Egg Products (67-75), WPSA, Zaragoza.

13. Küçükyılmaz K, Bozkurt M, Herken EN, Çınar M, Çatlı AU, Bintaş E, Çöven F (2012): Effects of rearing systems on performance, egg characteristics and immune response in two layer hen genotype. Asian-Aust $\mathrm{J}$ Anim Sci, 25, 559-568.

14. Petek M, Alpay F, Gezen ŞŞ, Çıbık R (2009): Effects of housing system and age on early stage egg production and quality in commercial laying hens. Kafkas Üniv Vet Fak Derg, 15, 57-62.

15. Pistekova V, Hovorka M, Vecerek V, Strakova E, Suchy P (2006): The quality comparison of eggs laid by laying hens kept in battery cages and in a deep litter system. Czech J Anim Sci, 51, 318-325.

16. Rehman MS, Mahmud A, Mehmood S, Pasha TN, Hussain J, Khan MT (2017): Comparative evaluation of egg morphometry and quality in Aseel hens under different rearing systems. J Appl Poult Res, 26, 401-409.

17. Resmi Gazete (22 Kasım 2014 tarihli ve 29183 sayılı) (2014a): Yumurtacı Tavukların Korunması İle İlgili Asgari Standartlara İlişkin Yönetmelik.

18. Resmi Gazete (20 Aralık 2014 tarihli ve 29211 sayılı) (2014b): Türk Gıda Kodeksi Yumurta Tebliği No: 2014/55.

19. Singh R, Cheng KM, Silversides FG (2009): Production performance and egg quality of four strains of laying hens kept in conventional cages and floor pens. Poult Sci, 88, 256-264.

20. Sokolowicz Z, Krawczyk J, Dykiel M (2018a): Effect of alternative housing system and hen genotype on egg quality characteristics. Emir J Food Agric, 30, 695-703.

21. Sokolowicz Z, Krawczyk J, Dykiel M (2018b): The effect of the type of alternative housing system, genotype and age of laying hens on egg quality. Ann Anim Sci, 18, 541-555.

22. SPSS ${ }^{2}$ (2013): 22.00 Computer Software: SPSS Inc, Headquarters, 233 s., Wacker Drive, Chicago, Illinois 60606, USA.

23. Stadelman WJ (1995): Quality Identification of Shell Eggs. 39-66. In: WJ Stadelman, OJ Cotterill (Eds), Egg Science and Technology, New York: Food Products Press, The Haworth Press Inc.

24. Şekeroğlu A, Sarıca M (2005): Serbest yetiştirme (free-range) sisteminin beyaz ve kahverengi yumurtacı genotiplerin yumurta verim ve kalitesine etkisi. J Poult Res, 6, 10-16.

25. TSE (2015): Türk Standardı Tavuk Yumurtast-Kabuklu, No: TS 1068.

26. Türkoğlu M, Sarıca M (2009): Tavukçuluk Bilimi (Yetiştirme, Besleme, Hastalıklar). 3. Basım, Bey Ofset Matbaac1l1k, Ankara.

27. USDA (2000). United States Department of Agriculture. Egg Grading Manual, Agriculturel Marketing Service, 
Agricultural Handbook, Number 75. Erişim Tarihi: 11.03.2019, Erişim Linki: https://www.ams.usda.gov/publications/content/egg-grading-manual

28. Van Den Brand H, Parmentier HK, Kemp B (2004): Effects of housing system (outdoor vs cages) and age of laying hens on egg characteristics. Br Poult Sci, 45, 745-752.

29. Varguez-Montero G, Sarmiento-Franco L, Santos-Ricalde R, Segura-Correa J (2012): Egg production and quality under three housing systems in the tropics. Trop Anim Health Prod, 44, 201-204.

30. YUM-BİR (2018). Yumurta Üreticileri Merkez Birliği, Yumurta Tavukçuluğu Verileri. Erişim Tarihi: 11.03.2019, Erişim Linki: https://www.yum-bir.org/UserFiles/File/yumurta-veriler2019web.pdf 